\title{
Age and Time Related Pheromone Production in Coffee Leafminer Leucoptera coffeella Guérin-Méneville (Lepidoptera: Lyonetiidae)
}

\author{
Eraldo R. Lima,* Evaldo F. Vilela, Terezinha M. C. Della Lucia and Livia M. S. Ataíde \\ Departamento de Biologia Animal, Entomologia, Laboratório de Semioquímicos, \\ Universidade Federal de Viçosa, 36570-000 Viçosa-MG, Brazil
}

\begin{abstract}
Este estudo foi feito para determinar o padrão de produção de feromônio sexual em glândulas de fêmeas virgens de Leucoptera coffeella como uma medida indireta do comportamento de chamamento. O composto principal, 5,9-dimetilpentadecano (1) foi extraído de glândulas de feromônio de fêmeas virgens para ser usado em dois experimentos. No primeiro foi investigado o efeito do tempo na produção do feromônio (extratos de 10 fêmeas de dois dias de idade em intervalos de duas horas) e no outro foi avaliado o efeito da idade das fêmeas na produção de feromônio (10 fêmeas com idade entre 1 e 5 dias após a emergência). Os extratos hexânicos contendo $5 \mathrm{ng} \mu \mathrm{L}^{-1}$ de 5,9-dimetilheptadecano (2) como padrão interno foram analisados por CG. As fêmeas tiveram as maiores quantidades de feromônio nas últimas quatro horas da escotofase e nas duas primeiras horas da fotofase. Fêmeas de um dia de idade produziram as maiores quantidades de feromônio na glândula.
\end{abstract}

This study was undertaken to access the pattern of sex pheromone production in glands of virgin females of Leucoptera coffeella as an indirect measure of the calling behavior. The major compound, 5,9-dimethylpentadecane (1) was extracted from pheromone glands of virgin females to be used in two experiments. The first one investigated the effect of the pheromone production time by females (extracts of 10 females with age of two days were carried out at 2-hour intervals). The other experiment evaluated the effect of female age on pheromone production (10 females with age ranged from 1 to 5 days after emergence class were used). Hexane extracts were made with $5 \mathrm{ng} \mu \mathrm{L}^{-1}$ of 5,9-dimethylheptadecane (2) as internal standard and analyzed by GC. Females had the highest amount of pheromone at the last four hours in the dark and the two first hours in the light period. One-day old females produced the highest amount of pheromone in the glands.

Keywords: Leucoptera coffeella, Lepidoptera, sex pheromone, 5,9-dimethylpentadecane, pheromone titer, coffee leaf miner

\section{Introduction}

Coffee leafminer (CLM) Leucoptera coffeella (GuérinMéneville) is an important and widely distributed pest among the main coffee-producing countries in the Neotropical region. ${ }^{1,2}$ In Brazil, it is considered a key pest of the coffee plant and causes losses up to $50 \%$ in production, due to the loss of photosynthetic area as a consequence of necrosis of the leaf surface, and early leaf fall when larval infestation is high. ${ }^{2}$ The inclusion of CLM sex pheromone in programs of integrated pest management of coffee through population monitoring has been pointed out by

*e-mail: mothman@ufv.br
Precetti and Parra. ${ }^{3}$ The sex pheromone was previously identified as 5,9-dimethylpentadecane (1). ${ }^{4}$

Several aspects of pheromone biology may change significantly with age. In some species, most females initiate calling within $24 \mathrm{~h}$ of emergence, ${ }^{5,6}$ while in other individuals vary considerably in the age at which calling starts. ${ }^{7.8}$ In several species, pheromone titer in the gland changes both with age and time during the scotophase or photophase..$^{9-12}$ To accomplish systematic pheromone ecology studies with CLM, it is necessary to know the diel pattern of pheromone release. Because of the small size, direct observation of the calling behavior is very difficult and inaccurate. This study was carried out to quantify the pattern of pheromone production in sex pheromone glands of virgin females as an indirect measure of the calling behavior. 


\section{Experimental}

\section{Insects and plants}

A CLM laboratory colony was established from larvae and pupae collected in the Viçosa county field, MG, Brazil. Rearing procedures followed the technique by Reis Jr. et al. ${ }^{13}$ at $20 \pm 0.5^{\circ} \mathrm{C}, 65 \pm 5 \%$ r.h. under a $12 \mathrm{~L}: 12 \mathrm{D}$ photoperiodic regime. In brief, the coffee green leaves, where the larvae develops and pupate, were maintained in the solution of benzyladenin $10^{-7} \mathrm{~mol} \mathrm{~L}^{-1}$. Small leaf fragments with pupae were individualized in $27 \mathrm{~mL}$ plastic containers until adult emergence. Individuals were sexed after emergence and females were fed with diluted honey at $10 \%$.

\section{Pheromone extraction}

Major compound (1) was extracted from pheromone glands of virgin females to be used in two experiments. The extraction was made by cutting off the terminal abdominal segments and soaked in $20 \mu \mathrm{L}$ of HPLC grade hexane containing $20 \mathrm{ng}$ of synthetic 5,9-dimethylheptadecane (2) as an internal standard. Samples were held in $100 \mu \mathrm{L}$ conical vials with teflon lined lids at $-20^{\circ} \mathrm{C}$ until analyzed.

\section{Pheromone quantification}

Analyses were carried out on a DB $5(25 \mathrm{~m} \times 0.32 \mathrm{~mm}$ $\times 0.25 \mu \mathrm{m}$ ) fused silica column, using a Shimadzu 17A v3 gas chromatograph, equipped with a splitless injector and flame ionization detector working in range zero. The column was kept at $80^{\circ} \mathrm{C}$ for $1 \mathrm{~min}$, increased to $230{ }^{\circ} \mathrm{C}$ at a rate of $6{ }^{\circ} \mathrm{C} \mathrm{min}-1$ and then to a final temperature of

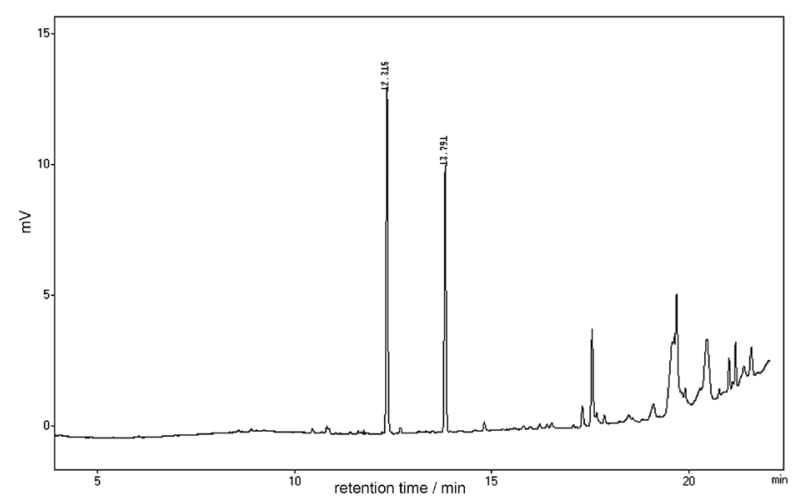

Figure 1. Chromatogram of extract from virgin female of Leucoptera coffeella representing the retention times of the sex pheromone 5,9-dimethylpentadecane (12.315 min; KI 1419/ DB-5) and the internal standard 5,9-dimethylheptadecane (13.791 min; KI 1785/ DB-5). For conditions, see Experimental Section.
$280{ }^{\circ} \mathrm{C}$ at a rate of $15^{\circ} \mathrm{C} \mathrm{min}^{-1}$. Nitrogen was used as carrier gas $\left(70 \mathrm{~mL} \mathrm{~min}^{-1}\right)$ and under these conditions the retention time of natural or synthetic (1) and synthetic (2) were $12.315 \mathrm{~min}$ (KI 1419/DB-5) and $13.791 \mathrm{~min}$ (KI 1785/DB-5), respectively (Figure 1). Compounds (1) and (2) were synthesized at the University of Hamburg by Dr. Wittko Francke. Natural compound (1) was identified in the pheromone gland extract comparing with retention time of synthetic compound (1). The periodicity of pheromone production and the age effect on the pheromone production were assessed by second degree polynomial regression analysis of the data.

\section{Experiments}

The first one investigated the effect of time of pheromone production by females. For this, extracts of 10 females aged two days were carried out at 2 hour intervals during $24 \mathrm{~h}$ (12D:12L) and analyzed individually. To access the effect of age on the pheromone production extracts from 10 females ranged from 1 to 5 days after emergence were used.

\section{Results and Discussion}

A typical chromatogram for all experiments is illustrated in (Figure 1). The separation of compounds in the column was very clear and the calibration of the equipment was severe in order to quantify very small amount of pheromone in the gland, so the quantification was considered accurate. In addition, the extraction of pheromone from the glands was quite clean despite the difficulty because the small size of the insect.

Females had the highest amount of pheromone in the last $4 \mathrm{~h}$ of the scotophase and the first two hours of the photophase (Figure 2). Amounts of pheromone were low in all other periods. The pattern of sex pheromone production throughout the photoperiodic cycle or calling behavior has not been investigated in this species. CLM reared in the laboratory at $12: 12$ (L:D) and $20^{\circ} \mathrm{C}$ exhibited a clear daily rhythm of pheromone content in the gland, with the peak at the end of scotophase and the lowest titer at the end of photophase. These results are in agreement with the time of mating found in experiments made in Porto Rico, El Salvador and Guatemala reported by Walter and Quintana. ${ }^{14}$ In that experiment the higher incidence of mating was at sunlight. The highest amount of pheromone in the glands is coincident with the period of calling behavior as in other moths, ${ }^{15-18}$ as well as the period of male response to pheromone ${ }^{19-21}$ and is the time of the highest frequency of matings. However, the time of mating differs from that reported by Michereff ${ }^{22}$ because, in the field, both 
synthetic pheromone and virgin females attracted males at 6 and $7^{\text {th }}$ hour of photophase, respectively, about $6 \mathrm{~h}$ after the time found in this experiment. The hours during which the largest amounts of the pheromone were extracted from the glands were at the time of lights on, indicating that this is the cue for pheromone production. As the photophase approached the amount of pheromone evaporating from the gland started to decrease until it reached a minimum level which remained low during the photophase. Further studies on the dynamics of pheromone release, may clarify whether synthesis at the end of scotophase followed by evaporation during the photophase could explain the differences in the results found in the present work and those found by Michereff. ${ }^{22}$ This work was done in the field and ours in the laboratory. The sexual behavior of phytophagous insects is often integrated in a variety of ways with their host plants. This integration may be manifested as effects or direct influences of host plants on insect physiology and behavior, including sex pheromone communication, that reflect strategies by insects to optimize mating and reproduction. Sex pheromone production and release may be affected by the presence of host plant material in a number of different ways, both direct and indirect. The stimulation by host plants of pheromone biosynthesis by insects has been reported for females of moths in the genus Helicoverpa and scolytid beetles. Production of sex pheromone by wild female corn earworm moths, Helicoverpa zea, is induced by the presence of host plants. ${ }^{23}$ Volatile chemical signals from corn silk, from solvent extracts of corn silk, or from tomatoes triggered the production of sex pheromone in terminal abdominal glands of $\mathrm{H} . \mathrm{zea} .{ }^{23}$ Moths removed from any host plant material refrain from reproductive activity, including sex pheromone production. A similar phenomenon was demonstrated with the related Helicoverpa phloxiphaga, which requires the presence of the host plant Castilleja indivisa (Texas paintbrush) for production of sex pheromone. ${ }^{24}$ In the bark beetle Dendroctonus brevicomis, male pheromone synthesis is stimulated by feeding on the host tree..$^{25}$ Feeding may trigger pheromone synthesis by removing inhibition of the corpora allata and triggering release of juvenile hormone. Juvenile hormone activates brain neurosecretory cells to release a stimulatory brain hormone that drives pheromone synthesis..$^{25}$ CLM is considered highly specific to coffee plants and is reasonable that this specificity can contribute to the expression of calling and pheromone release. Our extractions of pheromone in the glands were made when the females were in absence of coffee leaves and so this can produce a variation in the results we found. Further experiments should be done when the females are in contact with odors of coffee leaves.

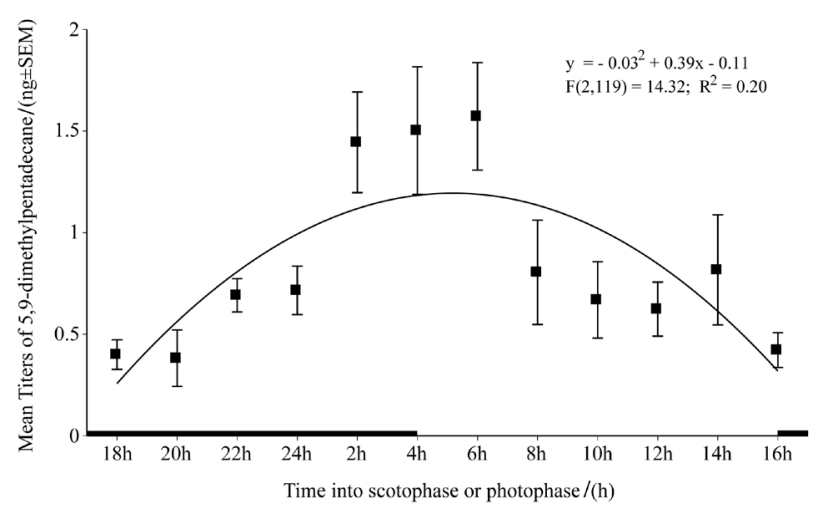

Figure 2. Mean titers of the major compound, 5,9-dimethylpentadecane, extracted from pheromone glands of two days old virgin females of Leucoptera coffeella. The scotophase is represented by the dark line on the time axis.

One day old females produced the highest amount of pheromone in the glands. After two days of emergence the titers of pheromone dropped significantly and remained low until females were 5 days old (Figure 3). In L. coffeella females the pheromone titers change with age and the drop of pheromone content has a different pattern found in other insects. ${ }^{26,27}$ The pheromone titers in newly emerged is probably the best level to elicit male response so is important to determine if the content of pheromone in aged females can attract males at the same level. If the mating is more frequent among newly emerged females this will have an important impact on the structure of mating in the population under mass trapping with pheromones. This hypothesis can be tested by subjecting the population to high amounts of pheromone in a way that pheromone traps with the right dose of pheromone can compete with feral females. $^{28}$

In our study, the quantification of $\mathbf{1}$ was done taking in account a stereoisomeric mixture because the absolute configuration of the natural pheromone still remains unknown. ${ }^{28-30}$ However, in field experiments using all the four possible stereoisomers synthesized by Kuwahara et al. ${ }^{29}$

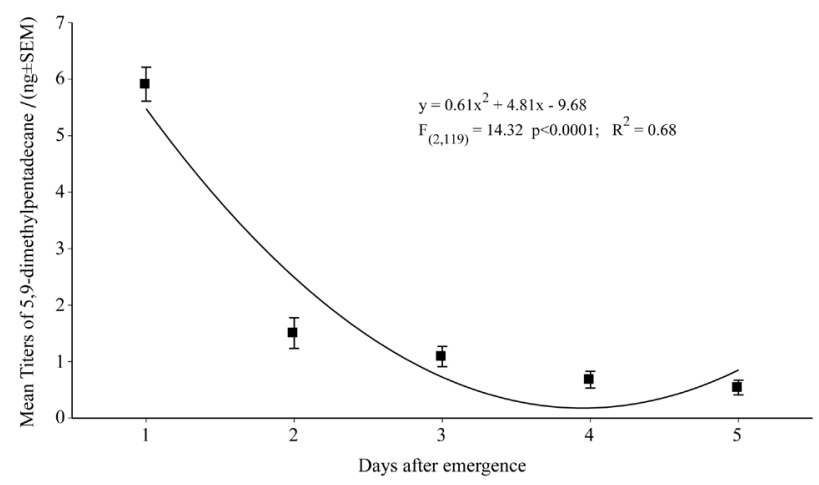

Figure 3. Mean titers of the major compound, 5,9-dimethylpentadecane extracted from pheromone glands of virgin females of Leucoptera coffeella from 1 to 5 days after emergence. 
it was observed that the traps baited with pure stereoisomers were poor attractive $\mathrm{e}^{30}$ while the binary mixture of the $5 \mathrm{~S}, 9 \mathrm{~S}$ (1) and 5R,9S-(1) isomers were attractive comparable to a stereoisomeric mixture of (1). ${ }^{32,33}$

\section{Acknowledgments}

We thank CNPq and PNP\&D-Café for the financial support (grant to E.R.L., E.F.V. and T.M.C.D.L.). We are in debt with Prof. Wittco Francke (University of Hamburg) for sending us the synthetic compounds.

\section{References}

1. De Leon, A. S.; Rev. Cafetalera 1984, 6, 244.

2. Souza, J. C.; Reis, P. R.; Bicho Mineiro: Biologia, Danos e Manejo Integrado; Circular Técnica Epamig 1992, 25.

3. Precetti, A. A. C. M.; Parra, J. R. P.; O Solo 1981, 71, 7.

4. Francke, W.; Tóth, M.; Szöcs, G.; Krieg, W.; Ernest, H.; Buschmann, E.; Z. Naturforsch., B: Chem. Sci. 1988, 43, 787.

5. Webster, R. P.; Cardé R. T.; J. Insect Physiol. 1982, 28, 933.

6. West, R. J.; Teal, P. E. A.; Laing, J. E.; Grant, G. M.; Environ. Entomol. 1984, 13, 1399.

7. Howlader, M. A.; Gerber, G. H.; Can. Entomol. 1986, 118, 1221.

8. Szöcs, G.; Tóth, M.; Acta Phyt. Acad. Sci. Hung. 1979, 14, 453.

9. Delisle, J.; McNeil, J. N.; Physiol. Entomol. 1987, 12, 157.

10. Raina, A. K.; Klun, J. A.; Stadelbacher, E. A.; Ann. Entomol. Soc. Am. 1986, 79, 128.

11. Schal, C.; Charlton, R. E.; Cardé, R. T.; J. Chem. Ecol. 1987, $13,1115$.

12. Snir, R.; Dunkelblum, E.; Gothilf, S.; Harpaz, I.; J. Insect Physiol. 1986, 32, 735.

13. Reis Jr, R.; Lima, E. R.; Vilela, E. F.; An. Soc. Entomol. Bras. 2000, 29, 849 .

14. Walker, D. W.; Quintana, V.; Proc. Entomol. Soc. Wash. 1969, 71,88 .
15. Baker, T. C.; Francke, W.; Millar J. G.; Löfstedt, C.; Hansson, B.; Du, J. W. P. L.; Phelan, P. L.; Vetter, R. S.; Youngman, R.; Todd, J. L.; J. Chem. Ecol. 1991, 17, 1973.

16. Babilis, N. A.; Mazomenos, B. E.; J. Insect Physiol. 1992, 38, 561.

17. Delisle, J.; Entomol. Exp. Appl. 1992, 63, 55.

18. Kamimura, M.; Tatsuki, S.; J. Insect Physiol. 1994, 40, 731.

19. Kehat, M.; Anshelevich, L.; Dunkelblum, E.; Fraishtat, P.; Greenberg, S.; Entomol. Exp. Appl. 1994, 70, 55.

20. Mitchell, E. R.; Tumlinson, J. H.; Fla. Entomol. 1994, 77, 237.

21. Mafra Neto, A.; Cardé, R. T.; Physiol. Entomol. 1995, 20, 229.

22. Michereff, M. F. F.; MSc Dissertation, Universidade Federal de Viçosa, Brazil, 2000.

23. Raina, A. K.; Kingan, T. G.; Mattoo, A. K.; Science 1992, 255 , 592.

24. Raina, A. K.; J. Chem. Ecol. 1988, 14, 2063.

25. Hughes, P. R.; Renwick, J. A. A.; Physiol. Entomol. 1977, 2, 289.

26. Raina, A. K.; Stadelbacher, E. A.; Ann. Entomol. Soc. Am. 1990, $83,987$.

27. Carrière, Y.; McNeil, J. N.; J. Insect Physiol. 1990, 36, 457.

28. Abdalla, F. C.; Velthuis, H.; Da Cruz Landim, C.; Duchateau, M. J.; Neth. J. Zool. 1999, 49, 251.

29. Kuwahara, S.; Liang, T.; Leal, W. S.; Ishikawa, J.; Kodama, O.; Biosci. Biotech. Biochem. 2000, 64, 2723.

30. Lima, E.R. PhD Thesis, Universidade Federal de Viçosa, Brazil, 2001.

31. Mori, K.; Tetrahedron: Asymmetry 2008, 19, 857.

32. Zarbin, P. H. G.; Princival, J. L.; Lima, E. R.; Santos, A. A.; Ambrogio, B. G.; Oliveira, A. R. M. ; Tetrahedron Lett. 2004, 45, 239.

33. Zarbin, P. H. G.; Villar, J. A. F. P.; Corrêa, A. G.; J. Braz. Chem. Soc. 2007, 18, 1100.

Received: December 6, 2007 Web Release Date: October 15, 2008 